\title{
DEVELOPMENT OF ECOLOGICAL PURE PRODUCTION OF SULPHURIC ACID PROPYLENE HYDRATION
}

\author{
Huseynova M.A. Email: Huseynova634@scientifictext.ru
}

\author{
Huseynova Matanet Arif qizi - Doctor of technical sciences by philosophy, Associate Professor, \\ DEPARTMENT OF PETROCHEMICAL TECHNOLOGY AND INDUSTRIAL ECOLOGY, FACULTY OF CHEMICAL \\ TECHNOLOGY, \\ AZERBAIJAN STATE UNIVERSITY OF OIL AND INDUSTRY, \\ BAKU, REPUBLIC OF AZERBAIJAN
}

\begin{abstract}
: in esterification reaction of the waste diisopropyl ester dehydration by isopropyl alcohol, distillated from the waste isopropyl alcohol distillated as a catalyst the cationite $K U-2$ have been used. Yield of esterificate in optimal conditions made up $86.45 \%$ from theoretical possible.

Synthesized product have been used as addition to industrial samples of diesel fuels and transformer oil for improvement of their low temperature oil with freezing point $\left(-52^{\circ} \mathrm{C}\right)$. After addition to highmentioned base sample of transformer oil $7 \%$ of synthesized by us compound a freezing temperature decrease up to $\left(-60^{\circ} \mathrm{C}\right)$.

Addition of esterificate in amount $20 \%$ mas. to diesel fuel, having freezing temperature $\left(-42^{\circ} \mathrm{C}\right)$, decrease it up to $\left(-52^{\circ} \mathrm{C}\right)$.

Keywords: diisopropyl ester, catalyst KU-2, esterificate, benzene, transformer oil.

\section{РАЗРАБОТКА ЭКОЛОГИЧЕСКИ ЧИСТОГО СЕРНОКИСЛОТНОГО ПРОИЗВОДСТВА ГИДРАТАЦИИ ПРОПИЛЕНА Гусейнова М.А.}

\author{
Гусейнова Матанет Ариф кызы - доктор философии по техническим наукам, доцент, \\ кафедра нефтехимической технологии и промылиленной экологии, химико-технологический факультет, \\ Азербайджанский государственный университет нефти и промышленности \\ 2. Баку, Азербайджанская Республика
}

\begin{abstract}
Аннотация: использование катионита КУ-2 в качестве катализатора реакции этерификаџии отходов абсолютирования диизопропилового эфира изопропилового спирта позволяет создать безотходную технологию получения изоприпилового спирта, превратить отходы производства в ценньй продукт.

Синтезированный продукт использовался в качестве дополнения к промышленным образиам дизельного топлива и трансформаторного масла для улучшения их низкотемпературного масла с точкой замерзания $\left(-520^{\circ} \mathrm{C}\right)$. После добавления к выработанному базовому образиу трансформаторного масла $7 \%$ синтезированных нами соединений снижают температуру замораживания до $-600^{\circ} \mathrm{C}$.

Добавление этерификата в количестве 20\% мас. на дизельное топливо, температура замораживания ($\left.420^{\circ} \mathrm{C}\right)$, уменьшает его до $-520^{\circ} \mathrm{C}$.
\end{abstract}

Ключевые слова: диизопропиловый эфир, КУ-2, этирификат, бензол, трансформаторное масло.

UDK 66.013

Production of isopropyl alcohol by sulphuric acid hydration of propylene in spite of imperfection from ecological point of view up to present time didn't lose its industrial significance.

By comparison of two industrial methods production of isopropyl alcohol by direct and sulphuric acid hydration of propylene it is necessary to notice the high conversion of propylene by sulphuric acid method and low (because of thermodynamical limitations) - by direct hydration.

In the work [1] a preferable use in industry of sulphuric acid method production of isopropyl alcohol was noticed. In given work an attempt to improve the ecological and technological-economical indices of sulphuric acid hydration of propylene by way of qualified use of wasters received in this production have been undertaken. The chemism of the process sulphuric acid production of isopropyl alcohol consists from the following stages: absorption of propylene by sulphuric acid by formation of sulphates; hydrolysis of alkylsulphates; separation of received product (isopropyl alcohol) and side product (diisopropyl ether) from sulphuric acid with following rectification by receive of chemically pure product [3,4]. It is obvious, that by absorption of propylene by sulphuric acid in conditions of industrial synthesis the side reactions of propylene oligomerization and propylene and its olygomers oxidation proceed. By dehydration of isopropyl alcohol and diisopropyl ether the olygomers and oxygencontaining compounds forming by that are stayed in cube residues.

The purposefulness of given research was investigation of composition, physical-chemical properties of sulphuric acid production of isopropyl alcohol wastes and research of the ways of its rational use.

In connection with highmentioned from cube residue of the column dehydration of diisopropyl ether a light fraction have been distillated, the analysis of which shown the availability content of diisopropyl ester and some 
amount of propylene dimer. Diisopropyl ether (DIE) and dimer of propylene may be used as highoctane components of gasoline. It is known that octane number of DIE determined by research method makes up 110 and by motor method - 99 [2]. Dimers and trimmers of propylee also possess by enough high antidetonating properties, the octane number of which by research method make up 106 [3]. The cube residue of the column dehydaration of DIE after distillation of light fraction was separated on the narrow fractions, composition and physical-chemical properties of which have been determined by use of spectral analysis (IR and UV spectrums), chromatographic and physical-chemical methods of analysis. Analysis shown a presence of propylene olygomers (tri-, tetra, penta-) in amount 76 mas.\% and oxygencontaining compounds in amount 24 mas.\%, mainly unsaturated aliphatic acids. The results of research were given in the works [4, 5] where also the composition of cube residue of the column dehydration of isopropyl alcohol (IA), consisting from 91-92 mas.\% of isopropyl alcohol and 8-9 mas.\% of mixture of propylene olygomers and unsaturated aliphatic acids is indicated. An analogical composition of the cube residues of the columns dehydration of DIE and IA is explained by that formation of IA and DIE take place in identical conditions absorption of propylene by sulphuric acid and hydrolysis of alkylsulphates. Forming by that olygomers of propylene and oxygencontaining compounds are stayed in corresponding wastes.

Before it have been shown that by drawing into reaction esterification by isopropyl alcohol of acid group, containing in wastes and also by isopropyl alcohol, containing in waste of dehydration a product have been received, which conditionally was named esterificate, which present itself the mixture from ester and unreacted olygomers of propylene. Esterefication was conducted in presence of catalyst - sulphuric acid, by that in optimal conditions of temperature and correlation of reagents a high yield equal 96.3 mas.\% from theoretical possible was achieved. At the present work as catalyst an ion exchange resin - cationite KU-2 have been used, which allow to prevent a stage washing of reacted reaction mass from acid, i.e. exclude formation of acid sewage, allow to conduct the process during a long time by continuous scheme, posses by high selectivity. Before experiment the cationite KU-2 was transferred in active $\mathrm{H}$-form, was dried after that a statical exchange capacity (SEC), corresponding to 4.84 [6] have been determined. In reaction esterification the fraction $140-250^{\circ} \mathrm{C}$ have been used, distillated from cube residue of the column dehydration of DIE and as a second reagent the isopropyl alcohol, distillated from the cube residue of the column dehydration of isopropyl alcohol have been used. The reaction have been conducted in three-neck flask, supplied by mixer, opposite cooler with Dine-Stark trap and contact thermometer. A temperature was maintained to the nearest degree ${ }_{-} 0.5^{0} \mathrm{C}$. At the reaction flask the determine amount of initial reagents have been put: fraction $140-250^{\circ} \mathrm{C}$ of cube residue of the column dehydration of DTE, isopropyl alcohol and catalyst - cationite KU-2. The process was continioned until a level of separated water, collected in Dine-Stark trap become constant. The received reaction mass was settled, filtrated, dried over calcium chloride and subjected to distillation for separation of received esterificate. Before, influence of temperature and molar correlation of reagents on yield catalyst have been studied [4]. In given work a possibility conducting of esterification reaction in presence of catalyst KU-2; influence of catalyst amount on yield and distribution of reaction products have been studied.

The research was conducted by condition of constant correlation of reagents and constant temperature, recognized an optimal in previous investigations by change only of catalyst amount.

The received experimental data are presented in tables $1,2,3$.

Table 1. Esterification in presence of $\mathrm{KU}-2$. Conditions: temperature $-87^{\circ} \mathrm{C}$, correlation fraction $\left(140-250^{\circ} \mathrm{C}\right)$ : isopropyl alcohol $=1: 9.8(\mathrm{~mol})$. Amount of $\mathrm{KU}-2-9.24$ mas. \%

\begin{tabular}{|c|c|c|c|c|c|}
\hline \multicolumn{2}{|c|}{ Was given } & \multicolumn{3}{c|}{ Was received } \\
\hline components & gram & mas.\% & components & gram & mas.\% \\
\hline Benzene & 87 & 31.39 & $\begin{array}{c}\text { Benzene unreacted fraction } \\
140-250^{\circ} \mathrm{C}\end{array}$ & $\begin{array}{c}87 \\
40.8\end{array}$ & $\begin{array}{c}1.39 \\
14.72\end{array}$ \\
\hline $\begin{array}{c}\text { Fraction 140-250 }{ }^{\circ} \mathrm{C} \text { waste of } \\
\text { DIE }\end{array}$ & 42.7 & 15.40 & $\begin{array}{c}\text { Unreacted isopropyl } \\
\text { alcohol }\end{array}$ & 110.1 & 39.72 \\
\hline Isopropyl alcohol & 119.5 & 43.11 & Esterificate KU-2 & 8.7 & 3.14 \\
& 28 & 10.10 & Waster losses & 0.2 & 0.07 \\
\hline KU-2 & 277.2 & 100 & In all & 2.4 & 0.87 \\
\hline In all & \multicolumn{2}{c}{} & & 100 \\
\hline
\end{tabular}

Yield of esterificate from theoretical is $21.3 \%$.

Table 2. Esterification in presence of $\mathrm{KU}-2$. Conditions: temperature- $87^{\circ} \mathrm{C}$, correlation fraction $\left(140-250^{\circ} \mathrm{C}\right)$ : isopropyl alcohol $=1: 9.8(\mathrm{~mol})$. Amount of $\mathrm{KU}-2-11.38$ mas. $\%$

\begin{tabular}{|c|c|c|c|c|c|}
\hline \multicolumn{2}{|c|}{ Was given } & \multicolumn{3}{c|}{ Was received } \\
\hline components & gram & mas.\% & components & gram & mas.\% \\
\hline Fraction $140-250^{\circ} \mathrm{C}$ & 42.7 & 14.99 & $\begin{array}{c}\text { Estereficate } \\
\text { Inreacted fraction 140- }\end{array}$ & 40.8 & 14.33 \\
\hline
\end{tabular}




\begin{tabular}{|c|c|c|c|c|c|}
\hline & & & $250^{\circ} \mathrm{C}$ & & \\
\hline Isopropyl alcohol & 119.5 & 41.98 & Unreacted isopropyl alcohol & $\begin{array}{c}98 \\
117.99\end{array}$ & 41.44 \\
\hline Benzene & 87 & 30.56 & Benzene water & $\begin{array}{c}87 \\
0.9\end{array}$ & $\begin{array}{c}30.56 \\
0.32\end{array}$ \\
\hline KU-2 & 35.5 & 12.47 & KU-2 losses & 35.5 & $\begin{array}{c}12.47 \\
0.88\end{array}$ \\
\hline In all & 284.7 & 100 & In all & 284.7 & 100 \\
\hline
\end{tabular}

Yield of esterificate from theoretical is $51.86 \%$.

Table 3. Esterification in presence of $\mathrm{KU}-2$. Conditions: temperature $-87^{\circ} \mathrm{C}$, correlation fraction $\left(140-250^{\circ} \mathrm{C}\right)$ : isopropyl alcohol $=1: 9.8(\mathrm{~mol})$. Amount of $\mathrm{KU}-2-13.42$ mas. $\%$

\begin{tabular}{|c|c|c|c|c|c|}
\hline \multicolumn{3}{|c|}{ Was given } & \multicolumn{3}{|c|}{ Was received } \\
\hline components & gram & mas.\% & components & gram & $\operatorname{mas} . \%$ \\
\hline $\begin{array}{c}\text { Fraction } 140-250^{\circ} \mathrm{C} \text { waste of } \\
\text { DIE }\end{array}$ & 42.7 & 14.76 & $\begin{array}{l}\text { Estereficate unreacted } \\
\text { fraction } 140-250^{\circ} \mathrm{C}\end{array}$ & $\begin{array}{l}44.5 \\
7.09\end{array}$ & $\begin{array}{l}15.39 \\
2.46\end{array}$ \\
\hline Isopropyl alcohol & 119.5 & 41.32 & Unreacted isopropyl alcohol & 108 & 37.35 \\
\hline Benzene & 87 & 30.09 & $\begin{array}{cc}\text { 1) } & \text { Benzol } \\
\text { 2) } & \text { water } \\
\end{array}$ & $\begin{array}{l}87 \\
0.9 \\
\end{array}$ & $\begin{array}{c}30.08 \\
0.31 \\
\end{array}$ \\
\hline KU-2 & 40.0 & 13.83 & KU-2 losses & $\begin{array}{l}40 \\
1.8\end{array}$ & $\begin{array}{c}13.83 \\
0.62\end{array}$ \\
\hline In all & 289.2 & 100 & In all & 289.2 & 100 \\
\hline
\end{tabular}

Analysis of data of the tables 1, 2, 3 show that increase of catalyst amount from 9.24 up to 13.42 mas.\% in composition of entered in reaction reagents essentially influence on yield of esterificate leading to increase from 21.3 up to $86.4 \%$ (accounting on fraction $140-250^{\circ} \mathrm{C}$ ) from theoretical possible amount.

Subsequent research was conducted by increase of catalyst amount up to 15.0-17.0 mas.\% in composition entered in reaction reagents. But it wasn't give an expreted result by increase of esterificate yield and therefore wasn't reflected in this article.

The physical-chemical properties and composition of received esterificates have been determined. The chromatographic analysis, conducted on chromatograph LXM-8MD in conditions: phase-polysorb, length of column $-2 \mathrm{~m}$, temperature $110-120^{\circ} \mathrm{C}$ shown existence in esterificate of $24 \%$ ester and $76 \%$ of propylene olygomers.

\section{References / Список литературы}

1. Donald L. Bardik, William L. Leffiner. Oil chemistry. Olimp-bizness. M., 2003.

2. Korolyov P.V., Pavlov O.S., Moskvichev Y.A. Pavlov S.Y. // Sythesis of diisopropyl ester and isopropyl alcohol in sulphocationite catalyst in presence of oxylol fraction II. Chemistry and chemical technology, 2004. V. 47. Issue 6.

3. Korolyov P.V., Pavlov O.S., Moskvichev Y.A. Pavlov S.Y. Production of isopropyl ester and isopropyl alcohol from propene-propane fraction// Chemistry and chemical technology, 2003. V. 46. Issue 9.

4. Paushkin Y.M., Vishnyakova T.V., Belov P.S. Practical works by oil chemical synthesis. M.: Chemistry, 1965.

5. Salimova N.A., Shakhverdiyeva F.M., Huseynova M.A. Analysis of the wastes of sulphuric acid production of isopropyl alcohol // News of the high technological schools of Azerbaijan. Baku, 2005. № 1 (35). P. 37.

6. Salimova N.A., Shakhverdiyeva F.M., Huseynova M.A. The ecologicaly harmless technology of sulphuric acid production of isopropyl alcohol. Engineering ecology. M., 2004. № 5. 